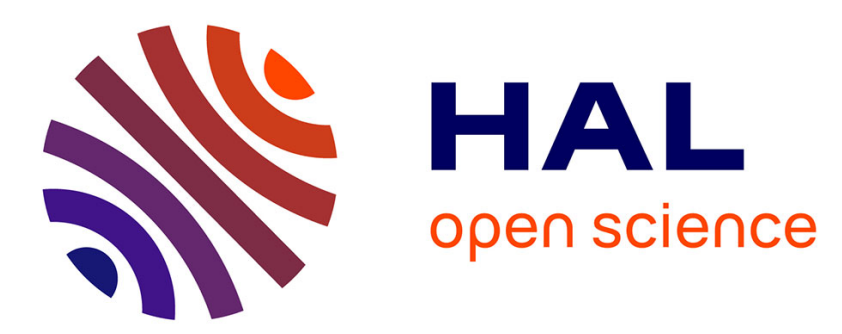

\title{
Cost-effective dye-sensitized solar cells based on commercial nanocrystalline titania and a ureasil gel electrolyte
}

\author{
M. Antoniadou, P. Lianos
}

\section{- To cite this version:}

M. Antoniadou, P. Lianos. Cost-effective dye-sensitized solar cells based on commercial nanocrystalline titania and a ureasil gel electrolyte. European Physical Journal: Applied Physics, 2010, 51 (3), pp.33211. 10.1051/epjap/2010113 . hal-00618496

\section{HAL Id: hal-00618496 \\ https://hal.science/hal-00618496}

Submitted on 2 Sep 2011

HAL is a multi-disciplinary open access archive for the deposit and dissemination of scientific research documents, whether they are published or not. The documents may come from teaching and research institutions in France or abroad, or from public or private research centers.
L'archive ouverte pluridisciplinaire HAL, est destinée au dépôt et à la diffusion de documents scientifiques de niveau recherche, publiés ou non, émanant des établissements d'enseignement et de recherche français ou étrangers, des laboratoires publics ou privés. 
Cost-effective dye-sensitized solar cells based on commercial nanocrystalline titania and a ureasil gel electrolyte

Maria Antoniadou and Panagiotis Lianos ${ }^{*}$

University of Patras, Engineering Science Dept., 26500 Patras, Greece

*e-mail address: lianos@upatras.gr

Key words: Dye-sensitized solar cells, nanocrystalline titania, ureasils

\begin{abstract}
Nanocomposite organic-inorganic dye-sensitised solar cells have been constructed by using solution processed materials that are easily deposited, they do not necessitate sealing or encapsulation and offer satisfactory efficiency. The main components of the cell are a nanocrystalline titania layer made of commercial Degussa P25 and a solid gel electrolyte made of a Ureasil precursor. Details on cell construction are given and show that the whole procedure can be upscaled for massive production.
\end{abstract}




\section{Introduction}

The employment of solution-processed materials in the construction of organic and organic-inorganic mesoscopic solar cells [1] carries a lot of promise for the fabrication of inexpensive photovoltaic devices. The effort for increasing light-toelectricity conversion efficiency is, of course, very important but cost effectiveness is equally important. There are four major factors, which define fabrication cost in organic solar cells: the cost of transparent electrodes, the cost of sealing or encapsulation, the cost of materials deposition processes and the cost of the component materials themselves. Organic materials are principally studied because they can be solution-processed and thus decrease the application cost. Transparent electrodes remain a serious cost-issue, since both Research laboratories and Industry mainly rely on commercial products, i.e. glass or polyethylene terephthalate (PET) substrates bearing a thin oxide layer, typically ITO (Indium Tin Oxide) or FTO (Fluorine doped Tin Oxide). Ongoing research [2] may lead to alternative less expensive products, but at this moment, transparent electrodes represent a large percentage of the device cost. Another major factor affecting device cost is sealing, in the case of liquid-electrolyte Dye-sensitized Solar Cells (DSC), or encapsulation, in the case of organic or hybrid organic-inorganic solar cells. In the present work, we have studied organic-inorganic solar cells, which do not necessitate sealing or encapsulation. Therefore, they can be more cost-effective. Organic-inorganic solar cells are usually based on the combination of a nanocrystalline metal oxide, which acts as electron acceptor and transporter, with a hole-transporting conjugated polymer $[3,4]$. In the present case, we employ nanocrystalline titania $\left(n-\mathrm{TiO}_{2}\right)$ in combination with an organic-inorganic nanocomposite solid gel synthesized by the sol-gel process [5]. The organic nanophase carries the $\mathrm{I}_{3}^{-} / \mathrm{I}^{-}$redox couple, which substitutes the holetransporting polymer. Sensitization of titania is made by a dye-sensitizer. Thus, the presently studied cells are in essence solid-state DSC devices.

The precursor for the gel was a ureasil having the structure shown in Fig.1. The same material has been reported in previous publications $[5,6]$. In the present work we adopt new procedures for depositing both titania and the gel, with capacity for upscaling and industrial application. 
<smiles>CCCCNC(=O)NC(C)CCOCC(C)NC(=O)NCC[Si](OCC)(OCC)O[Si](C)(OCC)OCC</smiles><smiles>O=S1(=O)CCCC1</smiles>

Figure 1. Structure of the Ureasil precursor and the solvent sulfolane.

\section{Experimental}

2.1 Materials All materials were from Aldrich unless otherwise specified. Cisbis(isothiocyanato)bis(2,2'-bipyridyl-4,4'-dicarboxylato)-ruthenium (II) (Ruthenium 535 or N3) was purchased from Solaronix, Switzerland; Commercial nanocrystalline titania was Degussa P25 and $\mathrm{SnO}_{2}: \mathrm{F}$ (FTO) transparent electrodes (Resistance 8 $\Omega /$ square) were purchased from Hartford, USA.

2.2 Synthesis of the Ureasil precursor The synthesis of the Ureasil of Fig.1 was reported in a previous publication [5]. Briefly, a Jeffamine, Poly(propylene glycol)bis(2-aminopropylether), of molecular weight 230 and 3Isocyanatopropyltriethoxysilane were mixed in tetrahydrofuran (THF) under reflux $\left(64^{\circ} \mathrm{C}\right)$ for 6 hours. The molar ratio was 1:2, respectively. The isocyanate group of 3 isocyanatopropyltriethoxysilane reacts with the amino groups of poly(propylene glycol)bis(2-aminopropylether) (acylation reaction) producing urea connecting groups between the polymer units and the inorganic part. After evaporation of THF under vacuum, a viscous material was obtained, which is stable at room temperature for several months (Ureasil, Fig.1).

2.3 Synthesis of the Ureasil gel containing the redox couple $\mathrm{I}_{3}^{-} \underline{\mathrm{I}}^{-} 2.4 \mathrm{~g}$ sulfolane (see Fig. 1 for chemical structure) were mixed under stirring with $0.7 \mathrm{~g}$ of the above Ureasil precursor, $0.4 \mathrm{ml}$ of $\mathrm{AcOH}$ and the necessary quantity of the ionic liquid 1methyl-3-propylimidazolium iodide (MPImI) that gives a concentration of about 0.5 
mol. $\mathrm{L}^{-1}$. Some cells were also tested by using simple iodide salts, like LiI and KI, but MPImI was judged best under all considerations. When the solution was clear, we added $I_{2}$ at a quantity that makes 0.05 mol. $L^{-1}$. Thus the ratio of $I^{-}$to $I_{2}$ was 10:1. Finally, we added about 0.5 mol. $\mathrm{L}^{-1} \mathrm{~N}$-methylbenzimidazole, which is known to raise the open-circuit voltage in DSCs [7,8]. The sol was stirred for several hours before application. During this period, a slow solvolysis takes place developing silica bonds between precursor chains and leading to condensation and gel formation [5].

$\underline{2.4 \text { Synthesis of } \mathrm{n}-\mathrm{TiO}_{2}}$ and dye adsorption A densely packed nanocrystalline titania $\left(\mathrm{c}-\mathrm{TiO}_{2}\right)$ layer was first deposited on FTO electrodes according to a previously published procedure [6,9]: $1.4 \mathrm{~g}$ of the non-ionic surfactant Triton X-100 was mixed with $7.6 \mathrm{ml}$ ethanol. Then we added $1.36 \mathrm{ml}$ glacial acetic acid $(\mathrm{AcOH})$ and $0.72 \mathrm{ml}$ of Titanium Tetraisopropoxide under vigorous stirring. After a few minutes stirring, the film was deposited by dipping and then it was left to dry in air for a few minutes. Finally, it was calcined at $550^{\circ} \mathrm{C}$. The temperature ramp was 20 degrees $/ \mathrm{min}$ up to $550^{\circ} \mathrm{C}$ and the sample was left for about $10 \mathrm{~min}$ at that temperature. The procedure can be repeated, if necessary. Each layer gave a thin nanostructered film of about 200 nm thickness, as measured by FE-SEM (see below). On the top of this c- $\mathrm{TiO}_{2}$ layer we deposited commercial Degussa P25. For this purpose, a paste of titania P25 was prepared as follows: $10 \mathrm{ml}$ of distilled $\mathrm{H}_{2} \mathrm{O}$ were mixed with $10 \mathrm{ml} \mathrm{EtOH}$ and $1 \mathrm{~g}$ of polyethylene glycol (PEG) 2000. Other PEG sizes may also apply. To this solution we progressively added Degussa P25 under vigorous stirring, followed by sonication. The maximum quantity of titania can vary according to the application. However, for the purposes of the present work it was $2 \mathrm{~g}$. When the mixture was visually a homogeneous solution it was put in a rotary evaporator to evaporate part of the solvent. The obtained paste was at the right viscosity to cast as a thin layer on top of the $\mathrm{c}-\mathrm{TiO}_{2}$ layer. It was finally calcined again at $550^{\circ} \mathrm{C}$. As soon as it was taken out of the oven, it was dipped in a $1 \mathrm{mmol} . \mathrm{L}^{-1}$ ethanolic solution of the dye $\mathbf{N} \mathbf{3}$ for several hours. The film was then heavily colored with adsorbed dye.

2.5 Cell construction Cells were made in the standard configuration. An FTO glass electrode was cut in the necessary dimensions and was carefully cleaned, first by washing with soap and then by subsequent sonication in isopropanol, water and acetone. On this clean electrode we applied the $\mathrm{n}-\mathrm{TiO}_{2}$ layers and adsorbed the dye- 
sensitizer N3, as already detailed. Then the film, colored with the adsorbed dye, was thoroughly rinsed with $\mathrm{EtOH}$, dried in a $\mathrm{N}_{2}$ stream and heated for a few minutes at $100^{\circ} \mathrm{C}$. The next step was to deposit the Ureasil sol enriched with sulfolane, Nmethylbenzimidazole and the $\mathrm{I}_{3}^{-} / \mathrm{I}^{-}$redox couple and to apply the counter electrode. One drop of the sol, prepared as detailed in paragraph 2.3, was placed on the top of the $\mathbf{N 3} / \mathrm{n}-\mathrm{TiO}_{2}$ film. A platinized FTO electrode was applied on the top and held together with a metal clip. It was left like this for a few hours. During this time, the sol becomes a solid gel and acts as adhesive resin steadily holding the two electrodes together. Platinization of the FTO electrode was made by evenly casting a $5 \mathrm{mmol} . \mathrm{L}^{-1}$ ethanol solution of sodium tetrachloroplatinate on the electrode and then heating up to $500^{\circ} \mathrm{C}$. The active area of the device was $1 \mathrm{~cm}^{2}(1 \mathrm{~cm} \mathrm{x} 1 \mathrm{~cm})$. Wire connection was made by using auto-adhesive copper ribbons. No encapsulation or sealing of the cell has been done and all measurements were performed under ambient conditions.

2.6 Instruments Illumination of the samples was made with a Peccell solar simulator PEC-L01. The intensity of incident radiation was measured with an Oriel RadiantPower meter. IV characteristics were drawn with a Keithley 2601 source meter. FieldEmission Scanning Electron Microscopy (FE-SEM) images were obtained with a LEO SUPRA 35VP device.

\section{Results and Discussion}

3.1 Analysis of cell components As already said, the purpose of the present work was to demonstrate the construction of a solar cell by employing simple procedures under ambient conditions, using solution processed materials. This cell does not need any sophisticated measures to function with satisfactory efficiency. One prime component of the cell is the nanocrystalline titania $\left(\mathrm{n}-\mathrm{TiO}_{2}\right)$ film, which is applied directly on the FTO transparent conductive electrode. It was judged necessary to apply it in two layers, as explained in paragraph 2.4. The first one was a thin layer of densely packed anatase nanoparticles of size smaller than $10 \mathrm{~nm}$. The texture of these films can seen in previous publications $[6,9,10]$. The second layer was a rough film composed of Degussa P25 nanoparticles. A FE-SEM of this top layer is seen in Fig.2. The size of the nanoparticles was $20-40 \mathrm{~nm}$. This layer presented an open structure, ideal for electrolyte sol penetration. A cross-sectional FE-SEM image of this double 
layer (not shown) permitted the measurement of layer thickness. It was $200 \mathrm{~nm}$ for the compact layer and $8 \mu \mathrm{m}$ for the rough top layer. The

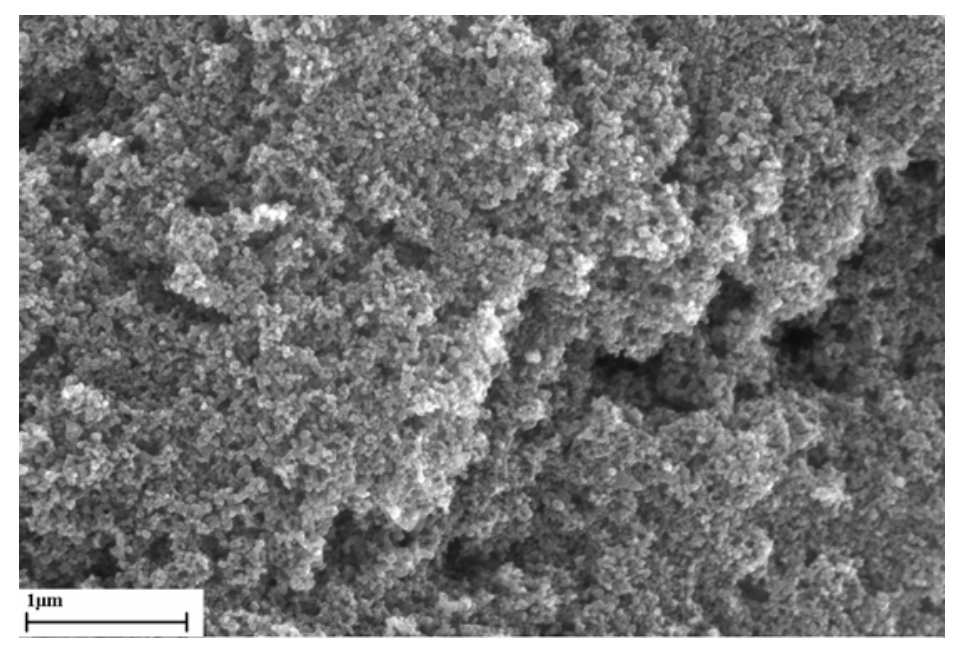

Figure 2. FE-SEM top view of the $\mathrm{n}-\mathrm{TiO}_{2}$ film

bottom layer was deposited by dipping, but we believe that it can be also applied by spraying or ink-jet printing. This matter is under study in our laboratory. The top layer was simply casted as a viscous paste and it can be applied by printing methods, like screen-printing.

The second basic component of the cell was the dye-sensitizer N3. This sensitizer was the same as the one used in our previous publications [cf. ref.[6]). N3 was adsorbed from a solution of the dye by simply immersing the $\mathrm{n}-\mathrm{TiO}_{2}$ film for several hours. When the film was taken out of the solution it was heavily colored with the adsorbed dye. Heavy dye uptake leads to higher cell efficiency. One of the advantages of the present double layer film was the heavy dye adsorption.

Third basic component was the gel electrolyte. This material is always applied as a sol to assure proper penetration into the $\mathrm{n}-\mathrm{TiO}_{2}$ nanostructure. We simply cast it on the top of the dye-functionalized $\mathrm{n}-\mathrm{TiO}_{2}$ and sandwiched it with the counter electrode on the top. This material is viscous enough to be applied by doctorblading techniques and fluid enough to penetrate titania nanostructure. Finally, the platinized counter electrode was set on the top and temporarily held with clips. After a few hours, silica bonds develop between the two electrodes, which are held permanently together without any support. No leak of the electrolyte is observed and no precautions are necessary for air or humidity penetration. The materials involved 
are not vulnerable to oxygen or humidity. Platinization of the counter electrode was obtained, as already said, by evenly casting a $5 \mathrm{mmol} . \mathrm{L}^{-1}$ ethanol solution of sodium tetrachloroplatinate on the electrode and then heating up to $500^{\circ} \mathrm{C}$.

Table 1. Data obtained by IV characterization of selected solar cells. All cells contained dye sensitizer $\mathrm{N} 3$ and $\mathrm{N}$-methylbenzimidazole and were exposed to radiation from a solar simulator set at $100 \mathrm{~mW} / \mathrm{cm}^{2}$

\begin{tabular}{|l|cccc|}
\hline \multicolumn{1}{|c|}{$\mathbf{n}-\mathbf{T i O}$ layer composition } & $\begin{array}{c}\mathbf{J}_{\mathbf{s c}} \\
\left(\mathbf{m A} / \mathbf{c m}^{\mathbf{2}}\right)\end{array}$ & $\begin{array}{c}\mathbf{V}_{\mathbf{o c}} \\
(\text { Volts })\end{array}$ & $\mathbf{f f}$ & $\eta(\mathbf{\%})$ \\
\hline 2 layers of c- $\mathrm{TiO}_{2}($ about $400 \mathrm{~nm})$ & 3.1 & 0.75 & 0.61 & 1.4 \\
4 layers of c- $\mathrm{TiO}_{2}$ (about $\left.800 \mathrm{~nm}\right)$ & 6.9 & 0.77 & 0.60 & 3.2 \\
6 layers of c- $\mathrm{TiO}_{2}($ about $1.2 \mu \mathrm{m})$ & 7.8 & 0.78 & 0.61 & 3.7 \\
P25 alone $($ about $8 \mu \mathrm{m})$ & 8.5 & 0.79 & 0.49 & 3.3 \\
1 layers of c- $\mathrm{TiO}_{2}+\mathrm{P} 25$ layer & 12.5 & 0.81 & 0.51 & 5.2 \\
\hline
\end{tabular}

3.2 Cell IV characteristics Table 1 shows the obtained IV data for some cell variants. Illumination was made with a solar simulator set at $100 \mathrm{~mW} / \mathrm{cm}^{2}$. The active area was $1 \mathrm{~cm}^{2}$, therefore, the measured short-circuit current directly corresponds to the sort-circuit current density $\mathrm{J}_{\mathrm{sc}}$. Table 1 also gives the value of open-circuit voltage $\mathrm{V}_{\mathrm{oc}}$, fill factor ff and overall light-to-electricity conversion efficiency $\eta$. The value of $\eta(\%)$ is the product $100 \times \mathrm{J}_{\mathrm{sc}} \times \mathrm{V}_{\mathrm{oc}} \mathrm{x} \mathrm{ff} / \mathrm{P}$, where $\mathrm{P}$ is the incident light intensity. Since $\mathrm{P}=100 \mathrm{~mW} \cdot \mathrm{cm}^{-2}, \eta(\%)$ is simply the numerical product of the values in the three first columns of Table 1.

The first three rows of Table 1 demonstrate the performance of the densely packed c- $\mathrm{TiO}_{2}$ layer alone and the effect of increasing its thickness. The quantity of adsorbed dye $\mathbf{N} \mathbf{3}$ increased with layer thickness, as can be seen by UV-Vis absorption spectrophotometry (not shown). Indeed, increasing of $n-\mathrm{TiO}_{2}$ thickness resulted in increasing the cell efficiency. The thickest 6-layer $\mathrm{c}-\mathrm{TiO}_{2}$ film was more efficient than that obtained with titania made of P25 alone $\left(4^{\text {th }}\right.$ row of Table 1$)$ and less efficient than cells made of the proposed combination of c- $\mathrm{TiO}_{2}$ with $\mathrm{P} 25$ ( $5^{\text {th }}$ row of Table 1). Obviously, comparable efficiencies can be obtained by using multiple layers of $\mathrm{c}-\mathrm{TiO}_{2}$, however, this type of $\mathrm{n}-\mathrm{TiO}_{2}$ deposition is tedious and thus more costly than the employment of commercial $n-\mathrm{TiO}_{2}$ paste, which makes the deposition technique fast and easy. There is, nevertheless, one more criterion that could decide 
the choice of the one or the other deposition technique: $\mathrm{c}-\mathrm{TiO}_{2}$ multiple layers make a relatively thin and transparent overall layer, contrary to thick Degussa P25 films, which are not transparent. If transparency is the target, then multiple layer deposition of $\mathrm{c}-\mathrm{TiO}_{2}$ will be necessary. The efficiency of the above cells is smaller that the efficiency of liquid electrolyte DSCs [11]. However, the fact that they do not need sealing or any other protection measures, beneficially addresses their fabrication cost. The data of Table 1 were obtained in the presence of $\mathrm{N}$-methylbenzimidazole, which, as already said [7,8], improves the open-circuit voltage by affecting the semiconductor/electrolyte interface, where it is preferentially solubilized. Indeed, if $\mathrm{N}$-methylbenzimidazole were not present, the $\mathrm{V}_{\mathrm{oc}}$ values of Table 1 would have dropped by about $200 \mathrm{mV}$.

The ff values of Table 1 demonstrate the importance of the role played by the densely packed titania c- $\mathrm{TiO}_{2}$. Compact titania allows higher connectivity between nanoparticles and thus easier electron transport. This is reflected in the higher value of the fill factor of the cell. On the contrary, ff was much smaller in the case of the P25 alone and improved in the presence of the underlying $\mathrm{c}-\mathrm{TiO}_{2}$. Consistent with this result was also the finding that by decreasing the light intensity down to $25 \mathrm{~mW} . \mathrm{cm}^{-2}$ the fill factor increased, but this increase was small in the case of $\mathrm{c}-\mathrm{TiO}_{2}$ alone $(0.61$ $0.64)$ and large in the case of P25 alone (0.49-0.63). The decrease of the fill factor with increasing illumination level is common to all solar cells, since their capacity of charge transport cannot respond to very high levels of charge carrier generation. Obviously, this capacity is higher in the presence of $\mathrm{c}-\mathrm{TiO}_{2}$ and for this reason, the combination of $\mathrm{P} 25$ with c- $\mathrm{TiO}_{2}$ was judged necessary.

One of the factors affecting cell cost is the presence of Pt catalyst on the counter electrode. No substituent has so far been found for Pt. We have tried some other noble metals, like $\mathrm{Au}, \mathrm{Ag}$ and $\mathrm{Pd}$. With most of them, the results were disappointing. An exception is Palladium, which gives cells with efficiency only 2030\% lower than Pt. Therefore, Pd may substitute Pt albeit with lower performance. This subject is, however, further studied in our laboratory.

\section{Conclusions}

This work demonstrates that a solid state DSC solar cell with satisfactory efficiency of more than $5 \%$ can be easily constructed by using easily deposited n$\mathrm{TiO}_{2}$ and an organic-inorganic solid gel electrolyte based on a ureasil precursor also 
easily synthesized. No sealing and no encapsulation is necessary for these cells. Cell assembly is simply done at ambient conditions by gluing the two electrodes together using the gel electrolyte itself as adhesive resin.

\section{Acknowledgements}

We are grateful to Dr.V.Drakopoulos for the FE-SEM measurements and to Prof.E.Stathatos for very interesting discussions concerning this work.

\section{References}

1. F. C. Krebs, Sol. Energy Mater. Sol. Cells 93, 349 (2009).

2. M. Garganourakis, S. Logothetides, C. Pitsalidis, N. A. Hastas, K. Breza, A. Laskarakis, N. Frangis, Thin Solid Films, In Press (2009).

3. F. C. Krebs, Y. Thomann, R. Thomann, J. W. Andreasen, Nanotechnology 19, 424013 (2008).

4. C. Goh, S. R. Scully, M. D. McGehee, J. Appl. Phys. 101, 114503 (2007).

5. E. Stathatos, P. Lianos, U. L. Stangar, B. Orel, P. Judeinstein, Langmuir 16, $8672(2000)$.

6. E. Stathatos, P. Lianos, Adv. Mater. 19, 3338 (2007).

7. E. Stathatos, P. Lianos, S. M. Zakeeruddin, P. Liska, M. Gratzel, Chem. Mater. 15, 1825 (2003).

8. S. A. Cerneaux, S. M. Zakeeruddin, M. Gratzel, J. Photochem. Photobiol. A 198, $186(2008)$

9. N. Strataki, N. Boukos, F. Paloukis, S. G. Neophytides, P. Lianos, Photochem. Photobiol. Sci. 8, 639 (2009).

10. M.Antoniadou, E.Stathatos, N.Boukos, A.Stefopoulos, J.Kallitsis, F.C.Krebs, P.Lianos, Nanotechnology 20(2009)495201.

11. M. Wang, M. Xu, D. Shi, R. Li, F. Gao, G. Zhang, Z. Yi, R. Humphry-Baker, P. Wang, S.M. Zakeeruddin, M. Gratzel, Adv. Mater. 20, 4460 (2008). 